\title{
Model-Based Analysis of Nitrate Concentration in the Leachate-The North Rhine-Westfalia Case Study, Germany
}

\author{
Frank Wendland ${ }^{1, *}$, Sabine Bergmann ${ }^{2}$, Michael Eisele ${ }^{2}$, Horst Gömann ${ }^{3}$, Frank Herrmann ${ }^{1}$ (1), \\ Peter Kreins ${ }^{4}$ and Ralf Kunkel ${ }^{1}$ \\ 1 Forschungszentrum Juelich, IBG-3, 52425 Juelich, Germany; f.herrmann@fz-juelich.de (F.H.); \\ r.kunkel@fz-juelich.de (R.K.) \\ 2 LANUV NRW, 47051 Duisburg, Germany; Sabine.Bergmann@lanuv.nrw.de (S.B.); \\ michael.eisele@lanuv.nrw.de (M.E.) \\ 3 LWK NRW, 50765 Köln-Auweiler, Germany; Horst.Goemann@LWK.NRW.DE \\ 4 Thünen-Institute, 38116 Braunschweig, Germany; peter.kreins@thuenen.de \\ * Correspondence: f.wendland@fz-juelich.de
}

Received: 20 December 2019; Accepted: 11 February 2020; Published: 15 February 2020

\begin{abstract}
Reaching the EU quality standard for nitrate $(50 \mathrm{mg} \mathrm{NO} / \mathrm{L})$ in all groundwater bodies is a challenge in the Federal State of North Rhine-Westfalia (Germany). In the research project GROWA+ NRW 2021 initiated by the Federal States' Ministry for Environment, Agriculture, Nature and Consumer Protection, amongst other aspects, a model-based analysis of agricultural nitrogen inputs into groundwater and nitrate concentration in the leachate was carried out. For this purpose, the water balance model mGROWA, the agro-economic model RAUMIS, and the reactive $N$ transport model DENUZ were coupled and applied consistently across the whole territory of North Rhine-Westfalia with a spatial resolution of $100 \mathrm{~m} \times 100 \mathrm{~m}$. Besides agricultural $N$ emissions, $N$ emissions from small sewage plants, urban systems, and NOx deposition were also included in the model analysis. The comparisons of the modelled nitrate concentrations in the leachate of different land use influences with observed nitrate concentrations in groundwater were shown to have a good correspondence with regard to the concentration levels across all regions and different land-uses in North Rhine-Westphalia. On the level of ground water bodies (according to EU ground water directive) $N$ emissions exclusively from agriculture led to failure of the good chemical state. This result will support the selection and the adequate dimensioning of regionally adapted agricultural $N$ reduction measures.
\end{abstract}

Keywords: nitrate; groundwater; source apportionment; modelling; nitrogen sources; leachate rate

\section{Introduction}

Excessive nitrate inputs into groundwater have been recognized as a main reason for failing drinking water standards for decades [1-6]. Agricultural $N$ emissions originating from mineral or organic fertilizers are regarded as the most relevant source of nitrate in groundwater worldwide [7]. Accordingly, strategies to cope with the nitrate pollution of groundwater are focused on controlling the agricultural sources of nitrate [8,9]. In Europe, this is reflected in the water legislation at the EU level, that is, the EU Water Framework Directive (EU-WFD) [10], the EU Marine Strategy Framework Directive [11], and the EU Nitrates Directive [12], obliging the polluter to implement measures to reduce the nitrogen impact on groundwater.

The EU-WFD [10] requires the assessment of the groundwater status at the level of groundwater bodies for both quantitative and qualitative status. The latter is assessed by comparing measured concentrations and trends at groundwater observation wells to groundwater quality standards or 
threshold values [13] and by extrapolating the findings at the monitoring sites to the area represented by these monitoring sites. As suggested by the European Commission in a guidance document on groundwater status and trend assessment [14] groundwater bodies in the EU are classified as being not in good status in cases of $20 \%$ or more of the total groundwater body area being polluted [15-17]. Consequently, a groundwater body is classified as failing in terms of good status due to nitrate in cases where the area represented by the monitoring station(s) shows nitrate concentrations above $50 \mathrm{mg}$ $\mathrm{NO}_{3} / \mathrm{L}$ and/or rising trends exceed $20 \%$ of the total groundwater body area.

In the groundwater bodies failing in terms of good status due to nitrate, measures reducing the nitrogen input into the aquifer have to be implemented $[10,11]$. Taking nitrate concentrations in groundwater above $50 \mathrm{mg} \mathrm{NO} / \mathrm{L}$ as a reference, the implementation of measures is limited to oxidized aquifers. Significant denitrification capacities are lacking in oxidized aquifers, and thus nitrate concentrations in the upper groundwater are directly correlated to the nitrate input $[18,19]$.

In reduced aquifers, such a relationship is missing due to denitrification processes [20-23], and thus the related groundwater bodies are in good status with regard to nitrate in spite of high nitrogen inputs. Consequently, no measures to reduce $N$ input have to be implemented in such cases. In North Rhine-Westfalia, such aquifers occur in the Northern parts of the Lower Rhine Embayment and parts of the Westphalian lowland. In this context, it must be remembered that the fossil pyrite and/or lignite particles involved in the denitrification process in aquifers are exhaustible resources [24,25]. Once this inventory of an aquifer is consumed, a dramatic nitrate concentration rise in groundwater can be observed [26,27]. Therefore, it is in generally not expedient to allow higher nitrogen inputs for reduced aquifers as is done for oxidized aquifers [28].

In order to ensure that the nitrate concentrations in oxidized aquifers will not exceed $50 \mathrm{mg} / \mathrm{L}$ and to conserve the natural denitrification capacity of reduced aquifers, the German Working Group on water issues of the Federal States and the Federal Government (LAWA) requires that the nitrate concentration in the leachate should not exceed $50 \mathrm{mg} \mathrm{NO} / \mathrm{L}$ [28]. Similar considerations are reflected in the groundwater strategies of other countries $[29,30]$. Against this background, the nitrate concentration in the leachate can be considered as the decisive starting-point to determine the $N$ reduction required [31].

In order to implement measures efficiently, a stepwise procedure can be used [18,32]. At first, the source areas contributing to measured nitrogen concentrations in groundwater beyond quality standards are identified within the groundwater bodies failing good chemical status. This is achieved by using modeled land use specific nitrate concentrations in the leachate to indicate nitrogen emission into groundwater. Subsequently, the absolute $N$ reduction required to reach the groundwater quality target in the areas concerned is determined. Finally, regionally adapted and accurately dimensioned $N$ reduction measures are selected and implemented.

Thus far, the model approach developed by the authors has focused on $N$ emissions from agriculture, assuming that these $N$ sources mainly have to be considered for determining the $N$ reduction need [33-35]. The predominance of agricultural $N$ sources in rural areas is quite obvious. In densely populated and industrialized regions, however, there are clear indications that also non-agricultural $N$ sources may contribute to high nitrate concentrations [36,37].

With an average population density of 525 inhabitants $/ \mathrm{km}^{2}$ [38], the Federal State of North Rhine-Westfalia represents a prime example for a densely populated region in Germany. In light of the above, there is a debate as to what extent non-agricultural $N$ emissions contribute to high nitrate concentrations. In cases where the nitrate concentrations in the leachate above $50 \mathrm{mg} / \mathrm{L}$ can be attributed to $N$ sources other than agricultural $N$ sources, agriculture alone cannot be obliged to implement $N$ reduction measures according to EU-WFD requirements [10]. In the regions where this is the case, $N$ reduction measures to counteract non-agricultural $N$ sources would have to be implemented.

Against this background, a simultaneous consideration of the $N$ emissions from all relevant $N$ sources is indispensable for assessing the entire $N$ loading of the leachate as well as the $N$ inputs into groundwater and surface waters. In practical terms, this means that in addition to the agriculturally produced $N$ emissions (agricultural $N$ balance surplus, atmospheric $N H x$ deposition), the $N$ emissions 
from urban systems; small sewage treatment plants seeping into groundwater; and the atmospheric NOx deposition from industry, household, and traffic should also be determined, doing so enables the identification of the "hot-spot areas", wherein the nitrate concentration in the leachate exceeds $50 \mathrm{mg} / \mathrm{L}$. Additionally, the proportion of the individual $\mathrm{N}$ sources with regard to the modelled nitrate concentration in the leachate in a certain region can be assessed objectively. The latter is an important prerequisite for addressing the regionally relevant $N$ emission source(s) and for deriving correctly dimensioned $N$ reduction measures.

\section{Materials and Methods}

The co-operation project GROWA+ NRW 2021 initiated by the Federal States' Ministry for Environment, Agriculture, Nature and Consumer Protection started at the end of 2015. In the context of the GROWA+ NRW 2021 project, the coupled agro-economic-hydrologic model network RAUMIS-mGROWA-DENUZ-WEKU-MONERIS [31] is applied and further developed in order to support the implementation process of the EU-Water Framework Directive, the EU Nitrates Directive, and the EU Marine Strategy Framework Directive in the Federal State of North Rhine-Westphalia. The questions to be answered in the GROWA+ NRW 2021 project include;

- The determination of the actual $N$ input into groundwater and surface waters;

- The identification of actual "hot spot" areas of $N$ pollution;

- The assessment of the necessary reduction of $N$ emissions to reach the EU quality standards;

- The prediction of the time lags until $N$ reduction measures will show effect (target achievement).

Nitrate concentration in the leachate is determined within the framework of an area-differentiated modeling of the diffuse and point source $N$ inputs into groundwater and surface waters. For this purpose, the model system [31,32], which had already proven its suitability in macro-scale applications on the level of States and river basins in Germany, was applied in NRW on the basis of statewide available input data. The individual sub-models and their interplay are documented in the literature [32-36] and will only be briefly described here. The interplay of the individual sub-models is summarized in Figure 1.

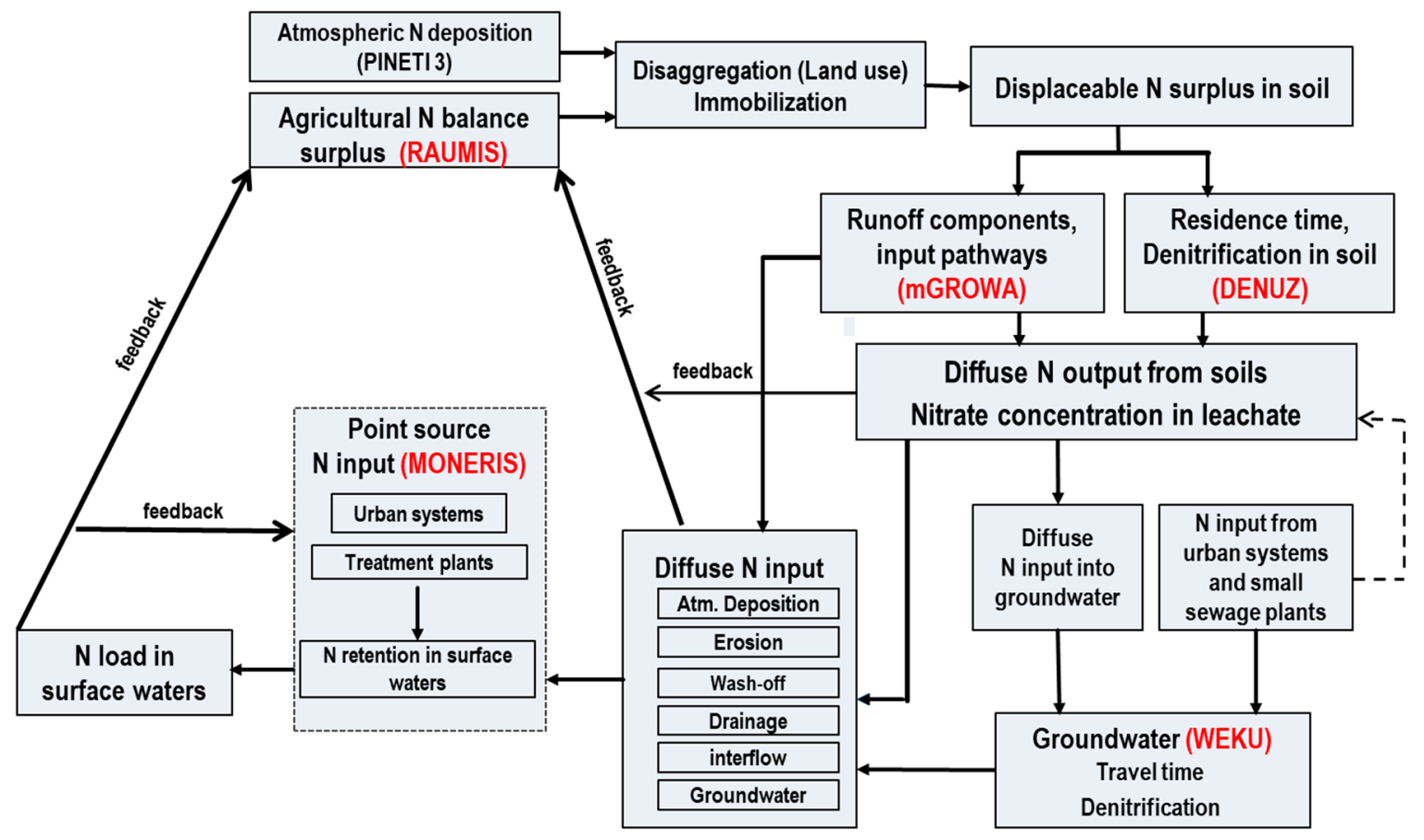

Figure 1. Simulation of nitrate concentration in the leachate in the framework of the coupled model system RAUMIS-mGROWA-DENUZ-WEKU-MONERIS. 
In the agricultural sector model RAUMIS [39], a set of agro-environmental indicators is linked to agricultural production. Currently, the model comprises indicators such as fertilizer surplus (nitrogen, phosphorus, and potassium), pesticides expenditures, a biodiversity index, and corrosive gas emissions. These indicators help to evaluate direct and indirect environmental impacts of policy-driven changes in agricultural production. Regarding diffuse water pollution, the indicator "nitrogen surplus" is of particular importance. Agricultural statistics with data, for instance on crop yields, livestock farming, and land use, were used to balance the nitrogen supplies and extractions for the agricultural area. The long-term nitrogen balance averaged over several vegetation periods is calculated by considering the organic nitrogen fertilization, the mineral nitrogen fertilization, the symbiotic $N$ fixation, the atmospheric $N$ inputs, the compost and sewage sludge spreading, and the $N$ removal with the crop substance $[40,41]$. As a rule, the difference between nitrogen supplies, primarily by mineral fertilizers and farm manure, and nitrogen extractions, primarily by field crops, leads to a positive $N$ balance.

A certain amount of the mineral $N$ surpluses in soils is denitrified to molecular nitrogen. Denitrification losses in the soil are calculated using the DENUZ model as a function of the diffuse $N$ surpluses, denitrification conditions, and the residence time of percolation water in the soil according to Michaelis-Menten kinetics [31,34]. The kinetical parameters are assessed on the basis of observed denitrification rates in soils [42,43] according to the geological substrate, the influence of groundwater, and perching water of the soils and the average residence time of perching water in the soil.

In order to determine the diffuse $N$ inputs into groundwater and surface waters according to individual pathways, the $N$ outputs from soil were subsequently coupled to runoff components. The latter were quantified with the water balance model mGROWA [44,45]. The mGROWA modelling approach comprises several sequential parts. Within the basic part, the hydrologic processes at the earth's surface and in the root zone of soil are simulated. In particular, soil moisture dynamics including percolation water movement, capillary rise from groundwater to the root zone, actual evapotranspiration, and total runoff generation are calculated on the basis of the multilayer soil water balance model BOWAB [46]. Total runoff values are used to derive runoff components including the leachate rate and input pathways for nutrients into groundwater and surface water.

Nitrate inputs into an aquifer may be reduced in groundwater by denitrification processes in a reduced (oxygen-free) groundwater milieu. This reactive nitrate transport in reduced groundwater is modelled using the WEKU model $[47,48]$ assuming a first-order denitrification kinetics depending on the nitrate inputs and the residence time in groundwater with a reaction constant of $0.17-0.56 \mathrm{a}-1$ [49-51].

$\mathrm{N}$ inputs from point sources and urban areas were taken into account using the procedures elucidated in the MONERIS model [52]. The nitrogen load in surface waters within a catchment is calculated by integration of the diffuse nitrogen inputs into the surface waters via the considered pathways calculated for each grid cell over the catchment area of the considered station plus the sum of the $N$ inputs from point sources. The observed $N$ loads, however, are influenced by nitrogen retention processes in the river itself, which may reduce the nitrogen loads of rivers. Nitrogen conversion in rivers is considered using the size of the catchment area, total runoff, the size of open water areas and temperature as inputs [53].

The summation of the modelled $N$ inputs from diffuse and point sources minus the riverine $N$ retention were compared to the measured $N$ loads from monitoring stations. The observed discharge and $N$ total concentrations were transformed into $\mathrm{N}_{\text {tot }}$-loads according to the OSPAR method [54].

The results of three sub-models were used for the simulation of the nitrate concentration in the leachate, namely, the mean long-term leachate rate determined with the water balance model mGROWA [44], the agricultural $N$ balance surplus assessed on the basis of the agro-economic model RAUMIS [39], and the reactive $N$ transport in soils determined on the basis of the DENUZ model [31].

Atmospheric $N$ deposition was taken into account, separated for the agricultural-related $N H x$ emission and the atmospheric NOx deposition originating from households, industry, and transport [55]. 
Both atmospheric $N$ sources contribute to the diffuse $N$ output from soils. Additionally, the $N$ emissions from urban systems and small sewage treatment plants were considered.

Equation (1) shows the general relation between the $N$ sources and the leachate rate in order to determine the nitrate concentration in the leachate. For an area covering analysis on the Federal State level, the individual terms of Equation (1) were determined:

$$
C_{\text {NO3 }}=\frac{4.43 \times(\text { Nsoil }+K K A+K S)}{0.01 \times Q_{s w}}
$$

where

$\mathrm{C}_{\mathrm{NO} 3}$ : nitrate concentration in the leachate $(\mathrm{mg} / \mathrm{L})$;

$Q_{s w}$ : leachate rate ( $\mathrm{mm} /$ year);

$K K A: N$ emissions from small sewage treatment plants ( $\mathrm{kg} \mathrm{N} /(\mathrm{KKA}$ and year));

$K S: N$ emissions from urban systems ( $\mathrm{kg} \mathrm{N} /($ community and year));

$N_{\text {soil }}$ : diffuse $\mathrm{N}$ output from soils ( $\mathrm{kg} \mathrm{N} /($ ha and year));

4.43: factor to convert nitrate-N (mg/L) to nitrate- $\mathrm{NO}_{3}(\mathrm{mg} / \mathrm{L})(-)$;

0.01: factor to convert $\mathrm{mm}$ in liter (-).

The leachate rate $\left(Q_{S W}\right)$ was determined on the basis of the mGROWA model [39], which simulates in the basic part the hydrologic processes at the earth's surface and in the root zone of soils. In particular, soil moisture dynamics including the movement of the leachate in soils, capillary rise from groundwater to the root zone, actual evapotranspiration, and total runoff generation were calculated in daily time steps on the basis of grass reference evapotranspiration, land use-specific crop coefficients, and a topography correction function. Additionally, mGROWA calculated the water balance for impervious surfaces (e.g., sealed surfaces in urban areas) and open water surfaces using approaches adapted to specific storage characteristics. The second part in mGROWA separated total runoff into the direct runoff components (natural interflow, drainage runoff, surface runoff, direct runoff from urban areas) and groundwater recharge from the total runoff by using base flow indices [56]. The leachate rate results from the difference between surface runoff including runoff from urban areas and total runoff and designates the water volume leaving the root zone downwards. It is in this regard not identical to groundwater recharge, which designates the water volume infiltrating into the aquifer.

The diffuse $N$ output from soil (Nsoil) included $N$ originating from two $N$ sources, on one hand the $N$ output from soil originating from agriculture (Nsoil(agri)), and on the other hand the $N$ output from soil originating from $N O x$ deposition. The diffuse $N$ output from soil originating from agriculture (Nsoil(agri)) was derived according to Equation (2) considering the agricultural-related $N$ loads. The corresponding diffuse $N$ output from soil originating from NOx (Nsoil (NOx)) was derived according to Equation (3). In both cases, two important processes controlling the $N$ losses from soils, these being $N$ immobilization (NI) and denitrification (ND), needed to be considered.

The diffuse $N$ output from soil originating from agriculture (Nsoil(agri)) included the agricultural $N$ balance surplus $\left(N_{u}\right)$ on a community level averaged over several vegetation periods provided by the regionally differentiating agricultural sector model RAUMIS [40]. As a rule, the difference between nitrogen supplies, primarily by organic and mineral fertilizers, and the nitrogen extractions, primarily by field crops, leads to a positive $N$ balance for the agriculturally used areas $\left(N_{u}\right)$.

$$
\begin{gathered}
\text { Nsoil(agri) }=N_{U}+N H x-N I-N D \\
N \operatorname{soil}(N O x)=N O x-N I-N D
\end{gathered}
$$

where

Nsoil (agri): $N$ output from soil originating from agriculture (kg N/ha·year);

Nsoil (NOx): N output from soil originating from NOx $(\mathrm{kg} \mathrm{N} /$ ha.year); 
$N_{U}$ : mean agricultural $N$ balance surplus ( $\mathrm{kg} \mathrm{N} /$ ha.year);

$\mathrm{NH}_{x}$ : mean atmospheric $\mathrm{NH} x$ deposition ( $\mathrm{kg} \mathrm{N} / \mathrm{ha} \cdot$ year);

NI: mean $N$ immobilization in soil ( $\mathrm{kg} \mathrm{N} /$ ha.year);

$N D$ : mean denitrification in soil ( $\mathrm{kg} \mathrm{N} /$ ha.year).

The $\mathrm{NH} x$ emission $\left(\mathrm{NH}_{x}\right)$, particularly from livestock, is the second most important agricultural $\mathrm{N}$ source that contributes to the diffuse $N$ output from soil originating from agriculture (see Equation (2)). It can be assumed that the entire agricultural share in atmospheric deposition was represented by the NHx deposition. Equivalent to the NHx deposition, it was assumed that the entire NOx deposition originating from households, traffic, and industry represented the diffuse $N$ output from soil originating from non-agriculture $N$ sources $(N \operatorname{soil}(N O x)$ ).

Both $N H x$ and NOx were derived from an official German-wide dataset on atmospheric Ndeposition determined in the framework of the PINETI project series (PINETI-3, Pollutant INputan EcosysTemImpact) [55] for the time series 2013-2015. In order to adapt the spatial resolution of the PINETTI-3 datasets to the spatial resolution of the modelling on NRW scale, the land-use specific $\mathrm{NH} x$ and NOx values available as $1 \times 1 \mathrm{~km}$ grids were disaggregated according to the land use grids of $100 \times$ $100 \mathrm{~m}$. Apart from its impact on agriculturally used land, the atmospheric NHx and NOx deposition also affected forests and settlement areas, and thus it had to be considered as area-covering data in the modelling of the nitrate concentration in the leachate.

The NOx deposition, as well as the sum of agricultural $N$ balance surpluses and atmospheric $\mathrm{NH} x$ deposition, do not correspond to the diffuse $N$ output from soils as two important processes controlling the $N$ losses from soils, that is, $N$ immobilization $\left(N_{I}\right)$ and denitrification $\left(N_{D}\right)$ have to be considered. For pasture and forested areas, it is assumed that a certain part of the $N$ input into soils is immobilized in the soil organic matter [57] and contributes to the development of biomass. The immobilization rates depend on the interplay of certain site conditions, for instance, leachate rates, soil texture, and topography. They can consequently be regarded as regionally variable and are determined in the framework of the model calibration for pasture and forested areas. For arable land, however, a significant $N$ immobilization in soil can be neglected [33].

The $N$ load resulting from the summation of agricultural $N$ balance surplus, atmospheric $\mathrm{NH} x$ and NOx deposition, and $N$ immobilization in soil is defined as the displaceable $N$ surplus in soil (see Figure 1). From this intermediate result, the $N$ output from soil is derived by subtracting the $N$ losses in soil due to denitrification. In contrast to $N$ immobilization, denitrification in soil takes place independent from the type of land cover. Equation (3) specifies the DENUZ approach to determine denitrification rates in soil.

$$
\frac{d N_{s} t_{\text {soil }}}{d t_{\text {soil }}}+D_{\max } \cdot \frac{N_{s} t_{\text {soil }}}{k+N_{s} t_{\text {soil }}}=0
$$

where

$N_{s} t_{\text {soil }}: N$ output from soil from agricultural $N$ sources and $N O x$ deposition after residence time $\left(t_{\text {soil }}\right)$ ( $\mathrm{kg} \mathrm{N} /($ ha.year));

$t_{\text {soil }}$ : residence times in soil (year);

$D_{\max }$ : maximum yearly denitrification rate in soil ( $\mathrm{kg} \mathrm{N} /($ ha.year));

$k$ : Michaelis-constant (kg N/(ha.year));

0 : displaceable $N$ surplus in soils ( $\mathrm{kg} \mathrm{N} /$ (ha·year)).

Using observed denitrification rates as a reference, the maximum denitrification rate $\left(D_{\max }\right)$ was assessed [18]. This was performed on the basis of a ranking of the soils predominantly according to their groundwater and perching water influence, as well as their organic carbon content $[34,35]$. Denitrification rates in soils were determined as a relationship between the realizable maximum annual denitrification rates assigned by the denitrification conditions and the related soil-specific reaction rates of denitrification $(k)$ under consideration of the effective residence times of the leachate in the 
root zone $(t)$. In this way, it is assumed that, for example, in a case were the residence time in a certain soil amounts to 6 months, the extent of denitrification is half of the maximum denitrification rate per year for the given soil.

The final result of the DENUZ model, that is, the diffuse $N$ output from soils from agricultural $N$ sources and NOx deposition, was subsequently used to calculate the nitrate concentration in the leachate according to Equation (1). Additionally, the $N$ outputs from urban systems (KS) and small sewage treatment plants (KKA) (see Equation (1)) were derived from directories about inhabitants and data about water management facilities (for the North Rhine-Westfalia-specific numbers, see Section 3.2.1).

\section{Results}

All input parameters and model results to calculate the nitrate concentration in the leachate were processed as area-covering data for the entire state of Northrhine-Westfalia with a spatial resolution of $100 \mathrm{~m} \times 100 \mathrm{~m}$. This resulted in a subdivision of the area of the Federal State into around 3.4 Mio individual grids.

The leachate rate (see Figure 2) diluted the $N$ emissions from agricultural and non-agricultural $N$ sources, as specified in Equation (1). It was calculated with the mGROWA model [39] for the hydrological reference period of 1981-2010. Using mean long-term leachate rates as a reference has two advantages with regard to the modelled nitrate concentrations in the leachate. On one hand, as a short-term climate-induced blurring of leachate rates was excluded, the modelled nitrate concentrations in the leachate were representative of the regional long-term hydrologic conditions. On the other hand, the regional varying $N$ emissions were related to a uniform leachate rate, which was of importance when the impact of $N$ reduction measures was assessed.

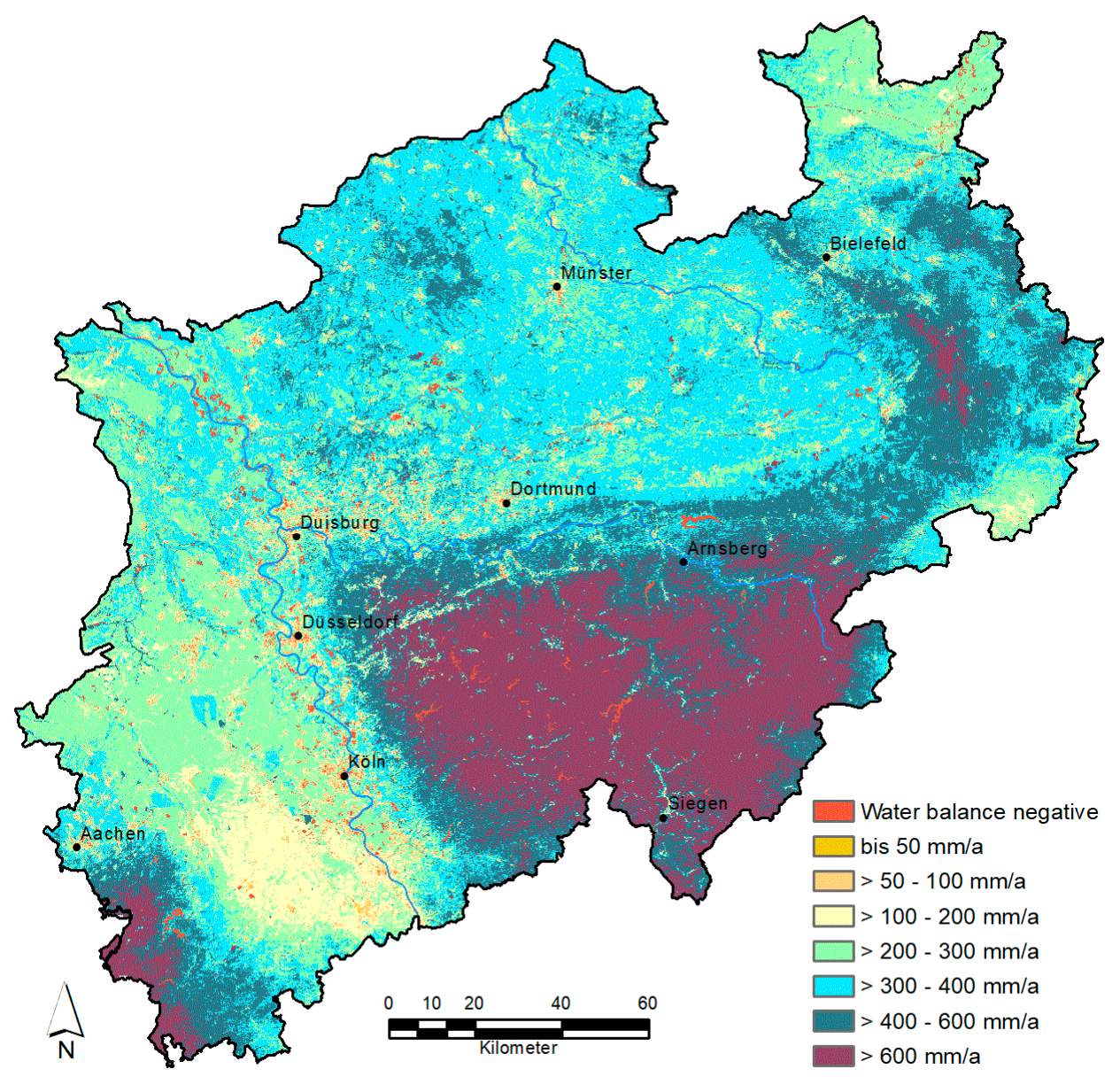

Figure 2. Mean long-term leachate rate of the hydrologic period of 1981-2010. 
The mean long-term leachate rates shown in Figure 2 reveal wide disparities between the regions. Whereas leachate rates of $600 \mathrm{~mm} /$ year or more frequently occurred in all consolidated rock regions (e.g., Rhenish Massif), leachate rates of less than $200 \mathrm{~mm} /$ year may have occurred in the southern part of the Lower Rhine embayment. There, the dilution of $N$ emissions from the different $N$ sources was up to three times higher in the consolidated rock regions.

\subsection{Nitrogen Emissions from Agricultural Sources and Resulting Nitrate Concentrations in the Leachate}

\subsubsection{Agricultural N Sources}

The $N$ sources taken into account for determining the $N$ output from soil originating from agriculture, that is, the agricultural $N$ balance surplus and the atmospheric $N H x$ deposition, are shown in Figure 3a,b, respectively.

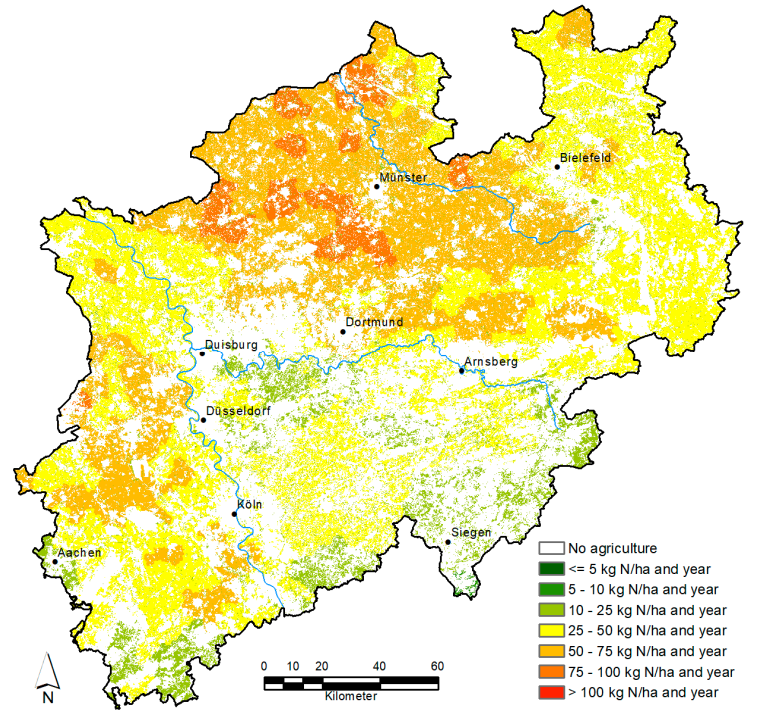

(a)

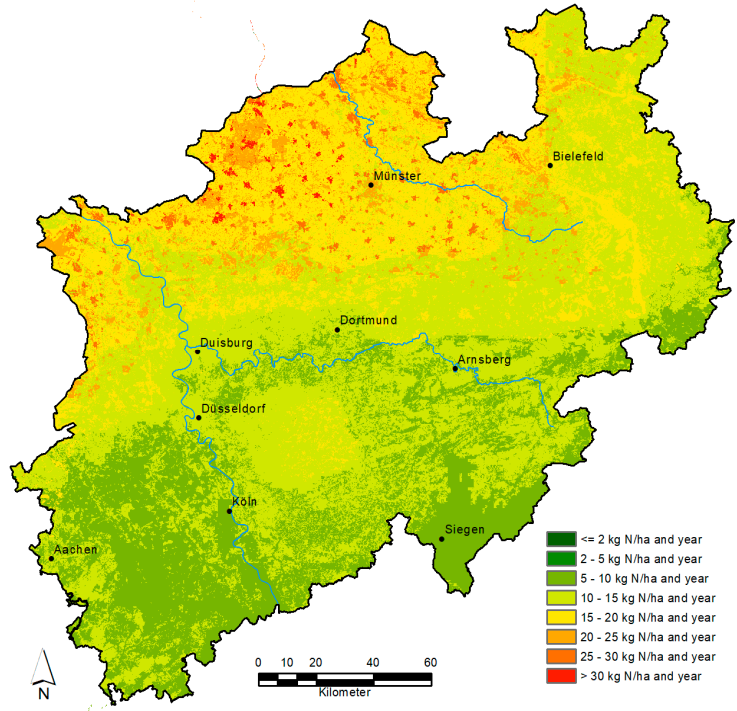

(b)

Figure 3. (a) Agricultural $N$ balance surplus and (b) atmospheric $N H x$ deposition.

In order to guarantee that crop- and withdrawal-related fluctuations were biased out, the agricultural $N$ balance surplus on a community level provided by the RAUMIS model [40] was determined as an averaged value for the period of 2014-2016. In total, the agricultural $N$ balance surplus in North Rhine-Westphalia summed up to around $82.400 \mathrm{t} \mathrm{N/a}$. Major differences became evident in cases where this sum was considered regionally differentiated (see Figure 3a). Agricultural $\mathrm{N}$ balance surpluses of less than $25 \mathrm{~kg} \mathrm{~N} /$ ha and year were found in regions where extensive grassland dominates (e.g., Rhenish Massif). In the food crop cultivation regions (e.g., Lower Rhine Embayment), where the $N$ demand was predominantly covered by well-controllable mineral fertilizer applications, the agricultural $N$ balance surpluses ranged between 25 and $50 \mathrm{~kg}$ N/ha per year. In contrast, nitrogen surpluses above $50 \mathrm{~kg} \mathrm{~N} /$ ha per year were determined for regions where livestock density was so high that the amount of organic fertilizers (and additionally applied mineral fertilizers) exceed the $N$ demand of the agriculturally used land. Areas in white indicate the non-agriculturally used forest and settlement areas.

In the agricultural regions with intensive livestock production in the north, the atmospheric $N H x$ deposition provided by the PINETI model summed up to more than $20-25 \mathrm{~kg} \mathrm{~N} /$ ha per year and locally to more than $30 \mathrm{~kg} \mathrm{~N} /$ ha per year [58] (see Figure 3b). To the south, that is, in greater distance from the regions with intensive livestock production, $N H x$ deposition rates between 10 and $20 \mathrm{~kg}$ N/ha per year predominated. This region extended from the northern part of the Lower Rhine embayment in the 
west to the Weserbergland in the east. In the southern part of the Lower Rhine Embayment, crop farms predominate. There, the atmospheric $\mathrm{NH} x$ deposition rarely exceeded $10 \mathrm{~kg} \mathrm{~N} /$ ha per year. The same NHx deposition rates were determined for the most southern parts of the Rhenish Massif situated in the lee of the Sauerland Mountains. Averaged over the entire Federal State of North Rhine-Westfalia, the atmospheric $\mathrm{NH} x$ deposition corresponded to a total of around 44,000 $\mathrm{t} \mathrm{N} / \mathrm{a}$.

\subsubsection{N Output from Soils Originating from Agricultural N Emission Sources}

In order to determine the $N$ output from soils, $N$ immobilization and denitrification (in soil) was considered. $N$ immobilization is related to the sum of the agricultural $N$ balance surpluses and atmospheric $\mathrm{NH} x$ deposition. Whereas the determined $\mathrm{N}$ immobilization rates comprised around $50 \%$ for the land-use category pasture, the $N$ immobilization rates for the land-use categories of coniferous forests and deciduous forests were in the range of $10 \%$ and $20 \%$, respectively. Averaged over the entire Federal State of North Rhine-Westfalia, $N$ immobilization retained around 18.500 tons N/a. Consequently, the displaceable $N$ surplus in soil, that is, the sum of agricultural $N$ balance surpluses plus atmospheric NHx deposition minus $N$ immobilization was in the range of around 108,000 $\mathrm{t} \mathrm{N/a.}$

The displaceable $N$ surplus in soil minus the $N$ losses in soil due to denitrification modeled with the DENUZ model (Figure $4 \mathrm{a}$ ) determined the $N$ output from soils (see Figure $4 \mathrm{~b}$ ). In the shallow brown earth soils of the Rhenish Massif, denitrification reduced the displaceable $N$ surplus in soil to less than $25 \%$. The low denitrification rates were due to the interaction of small residence times in the soil (often less than 3 months) and poor denitrification conditions in the soil.

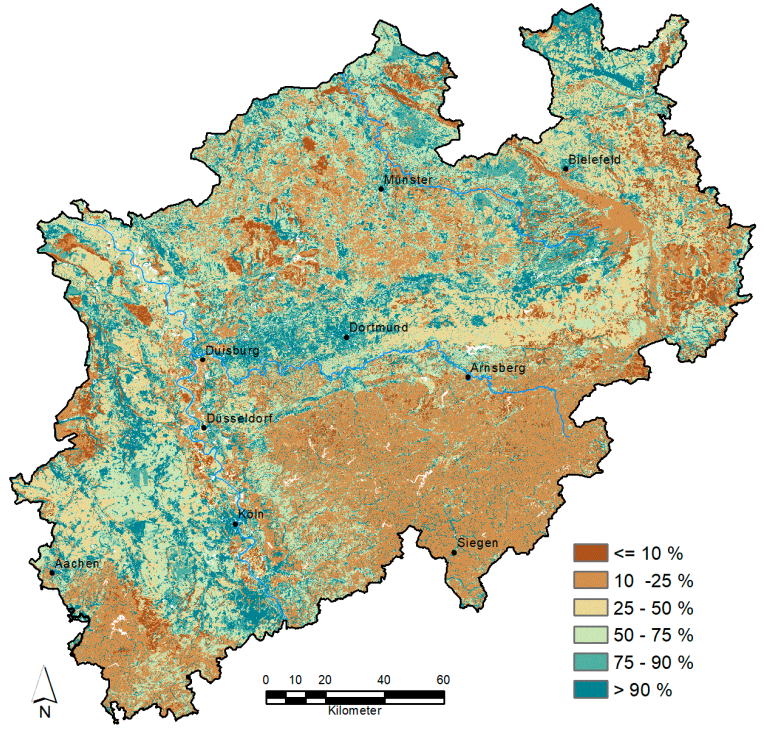

(a)

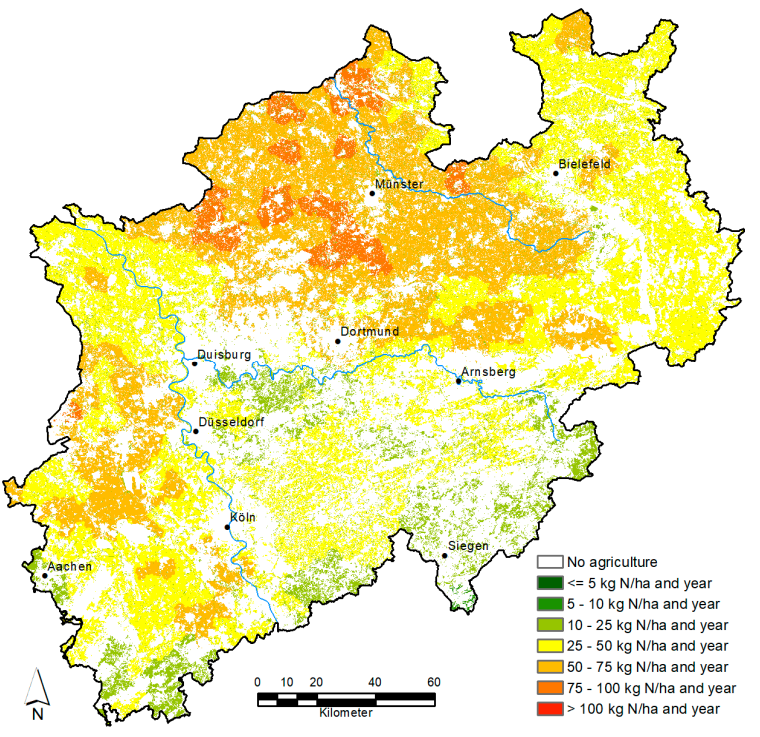

(b)

Figure 4. (a) Denitrification losses in soil relative to the displaceable $N$ surplus in soil, and (b) $N$ output from soils originating from agricultural sources.

In the fertile loess regions of North Rhine-Westfalia (Lower Rhine embayment, Soester Börde), up to $50 \%$ of the agricultural $N$ input into soils was denitrified. Although the denitrification capacity of the predominantly occurring luvisol was quite unfavorable, these soils displayed a high water storage capacity and relatively low leachate rates (see Figure 2). Consequently, residence times in soil was often in the range of 1 year (or more), and thus the maximum possible denitrification rates in soil could nearly be reached or even be exceeded. As shown in Figure $4 \mathrm{~b}$, the resulting $N$ output from soils in these regions ranged between 25 and $50 \mathrm{~kg} \mathrm{~N} / \mathrm{ha}$ per year.

Generally, high displaceable $N$ surpluses in soil occurred in the Münsterland basin in the Northern part of North Rhine-Westfalia. There, sandy podzol soils showing poor denitrification 
capacities alternated with loamy lowland soils (e.g., Gleyic soils) showing high denitrification capacities. Consequently, denitrification losses of more than $75 \%$ may be achieved in the lowland soils, whereas denitrification rates in the pozol soils hardly exceeded 25\% (see Figure $4 \mathrm{a}$ ). Accordingly, soils with $N$ outputs of less than $25 \mathrm{~kg} \mathrm{~N} /$ ha per year and soils with $N$ losses of more than $75 \mathrm{~kg} \mathrm{~N} /$ ha per year occurred closely adjacent to one another (see Figure $4 \mathrm{~b}$ ). In the core of the Münsterland, vast areas with $N$ outputs from the soil in the range of $75 \mathrm{~kg} \mathrm{~N} /$ ha per year were identified. There, soils with moderate denitrification capacities coincided with very high displaceable $N$ surpluses in soil. Clearly recognizable in Figure $4 \mathrm{~b}$ is the metropolitan area Rhein-Ruhr. As there were no other agricultural $N$ inputs other than the atmospheric $N H x$ deposition, the $N$ output from soil that can be assigned to agricultural $N$ emissions was below $5 \mathrm{~kg} \mathrm{~N} /$ ha per year.

Averaged over the entire Federal State of North Rhine-Westfalia, around $45 \%$ of the displaceable $N$ surplus in soil (around 108,000 t N/a) was denitrified, and thus the $N$ output from soil originating from agricultural $N$ emissions was reduced to approximately 69,000 t N/a.

\subsubsection{Nitrate Concentration in the Leachate Originating from Agricultural Sources}

The $N$ output from soil attributed to agricultural $N$ emissions (Figure $4 \mathrm{~b}$ ) were combined with the leachate rates (Figure 2) to determine the nitrate concentration in the leachate originating from agricultural sources (see Figure 5a). In Figure 5b, the areas where a nitrate concentration in the leachate exceeded $50 \mathrm{mg} \mathrm{NO}_{3} / \mathrm{L}$ are highlighted.

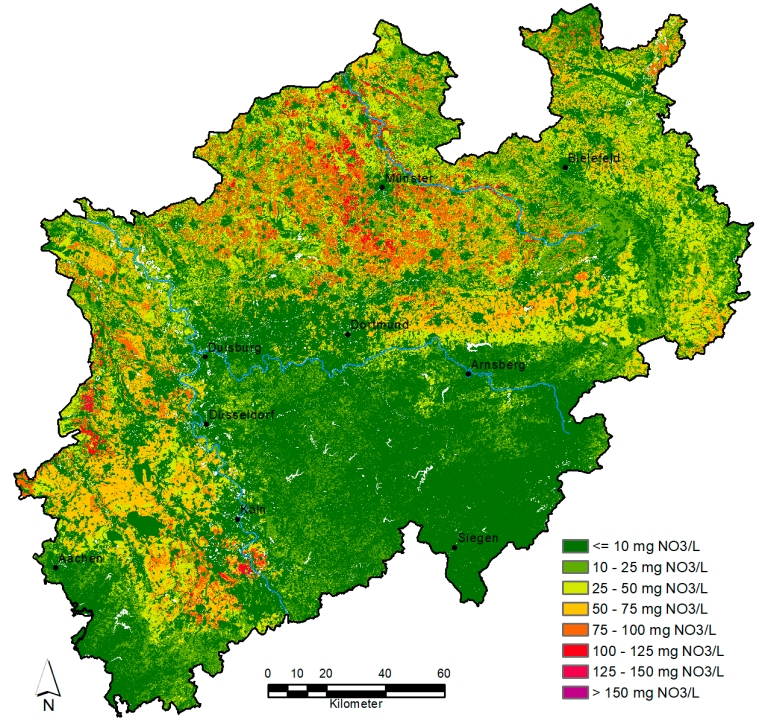

(a)

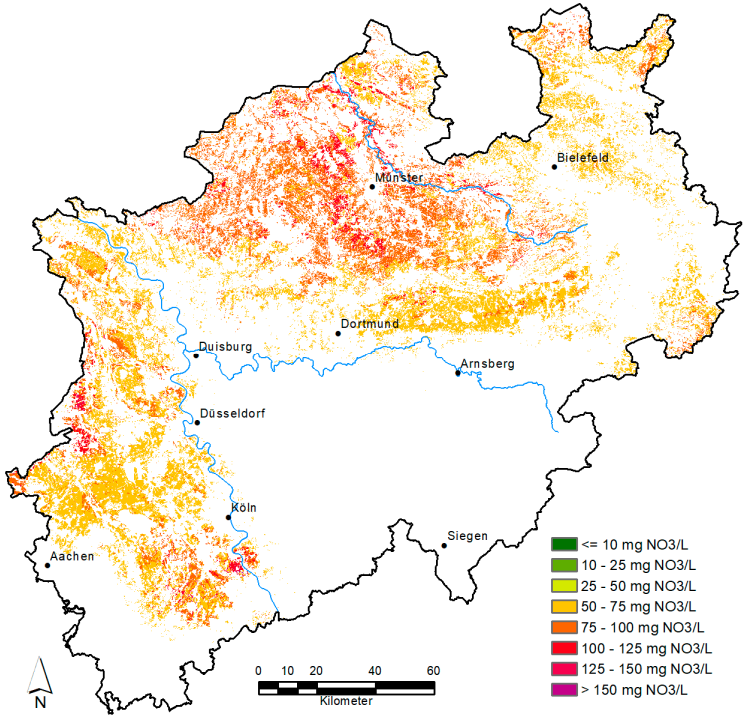

(b)

Figure 5. (a) Nitrate concentration in the leachate originating from agricultural sources, and (b) areas showing nitrate concentrations in the leachate above $50 \mathrm{mg} \mathrm{NO}_{3} / \mathrm{L}$ due to agricultural $\mathrm{N}$ emissions.

For many areas in the Münsterland, particularly high values arose due to the high livestock density, which led to an accordingly high nitrogen balance surplus. In the Lower Rhine Embayment, nitrate concentrations in the leachate between 50 and $75 \mathrm{mg} / \mathrm{L}$ predominated. There, moderate nitrogen balance surpluses arising from cash crop farms were combined with low leachate rates. Nitrate concentrations in the leachate below $25 \mathrm{mg} / \mathrm{L}$ could be found in the urbanized areas of North Rhine-Westfalia, as well as in the Rhenish Massif, where high leachate rates coincided with low $N$ emissions. Figure $5 b$ illustrates in this regard how yet again there was a remarkable extent of areas with nitrate concentrations in the leachate above $50 \mathrm{mg} / \mathrm{L}$ in the Lower Rhine Embayment and the Münsterland. 


\subsection{Nitrogen Emissions from Non-Agricultural Sources and Resulting Nitrate Concentrations in the Leachate}

The calculation of the nitrate concentration in the leachate due to non-agricultural $N$ sources included on one hand the $N$ emission from small sewage treatment plants and urban systems. On the other hand, it included the $N$ outputs from soil attributed to the NOx deposition from industry, traffic, and households (see Equation (3)).

\subsubsection{Non-Agricultural N Sources}

The $N$ output from urban systems (Figure 6a) was quantified on the basis of data provided by an actual management report about the development and level of sewage disposal in North Rhine-Westphalia [59]. According to this report, the total amount on nitrogen emitted from municipal waste water disposals (including indirect discharges) divided by all inhabitants resulted in $11 \mathrm{~g} N$ per day. Under the assumption that $15 \%$ of this disposal was released into groundwater due to leakage from the waste water systems, a uniform nitrogen release from urban systems into groundwater of $1.65 \mathrm{~g} \mathrm{~N}$ per inhabitant per day was estimated. The $N$ losses from urban systems determined in this way ranged between $10 \mathrm{~kg}$ and $50 \mathrm{~kg} \mathrm{~N} /$ ha per year. The highest values occurred, as expected, in densely populated regions along the river Rhine and the Ruhr area. On Federal State scale, the total $N$ losses from urban systems accumulated to approximately $11.200 \mathrm{t}$ N/a.

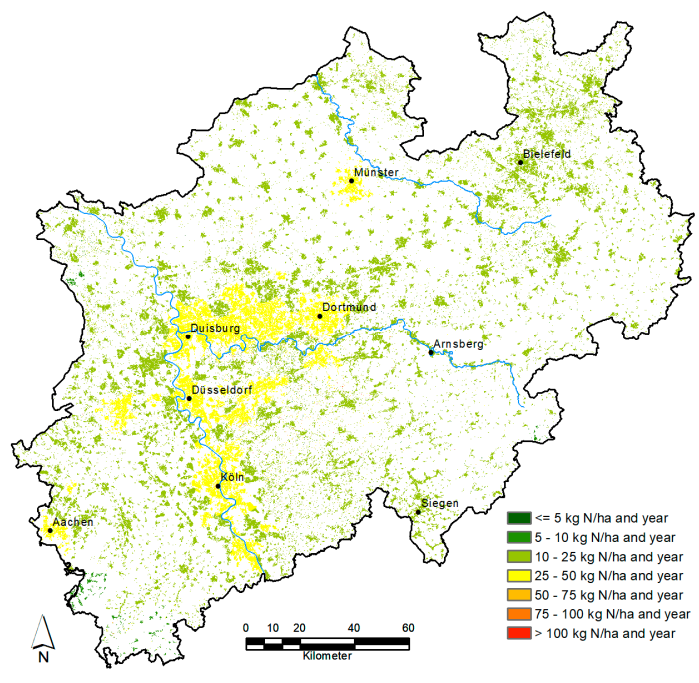

(a)

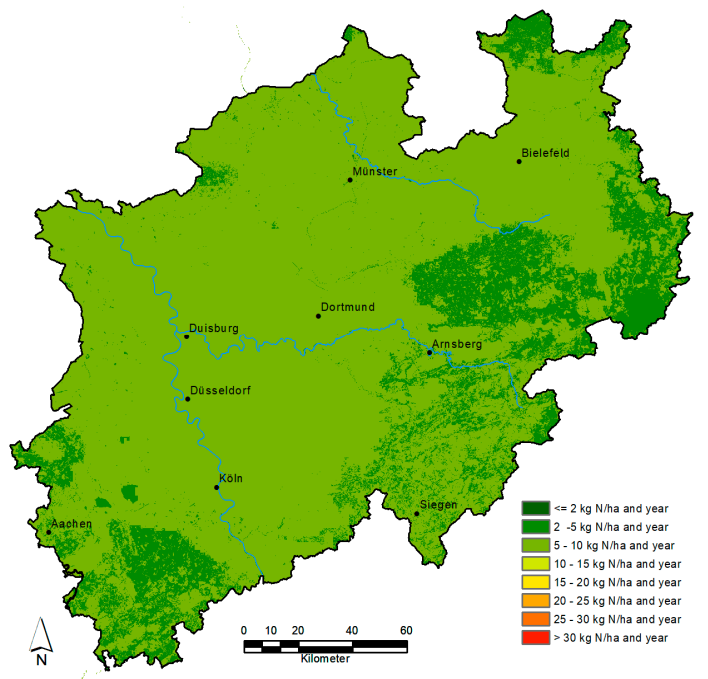

(b)

Figure 6. (a) Nitrogen output from urban systems and small sewage treatment plants, and (b) atmospheric NOx deposition (2013-2015).

For considering the $N$ output from small sewage treatment plants, the recorded annual $N$ emissions of around 20,000 individual facilities emitting into groundwater were taken into account [60]. For this purpose, the recorded $N$ loads were assigned to the corresponding $100 \times 100 \mathrm{~m}$ grids. In most of all grids concerned, the $N$ outputs from small sewage treatment plants showed values below $25 \mathrm{~kg} \mathrm{~N} / \mathrm{ha}$ per year. Higher $N$ outputs occurred locally only, but could reach $100 \mathrm{~kg}$ N/ha per year and more. At the Federal State level, the total $N$ loss of the small sewage treatment plants summed up to around $500 \mathrm{t}$ N/a. As the visibility of the individual $100 \mathrm{~m}$ grids was limited, the $N$ outputs from small sewage treatment plants are shown in Figure $6 a$, together with the $N$ output from urban systems.

The atmospheric NOx deposition originating from households, industry, and transport was provided from a Germany-wide dataset on atmospheric $N$ deposition [58]. Depending on the region, the $N$ output from soils from NOx deposition ranged between $<5$ to $>10 \mathrm{~kg} \mathrm{~N} /$ ha per year (see Figure $6 \mathrm{~b}$ ). For the total area of NRW, this relatively low average annual atmospheric NOx deposition summed up to around 20,000 tons of N/a. 


\subsubsection{Nitrate Concentration in the Leachate Originating from Non-Agricultural N Sources}

The $N$ output attributed to urban systems and small sewage treatment plants (Figure 6a), as well as the $N$ output from soil resulting from NOx deposition (Figure $6 \mathrm{~b}$ ) was combined with the leachate rates (Figure 2) to determine the nitrate concentration in the leachate originating from non-agricultural sources (Figure 7).

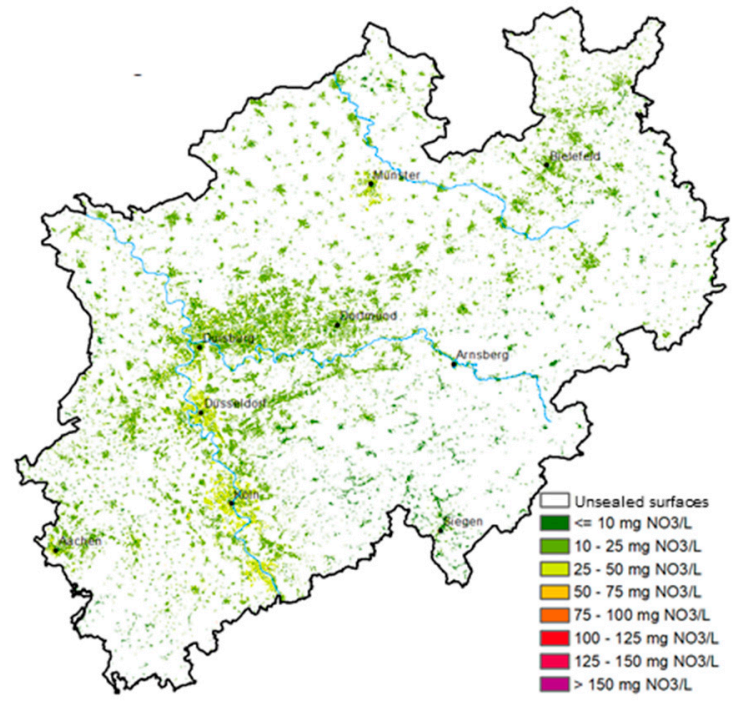

(a)

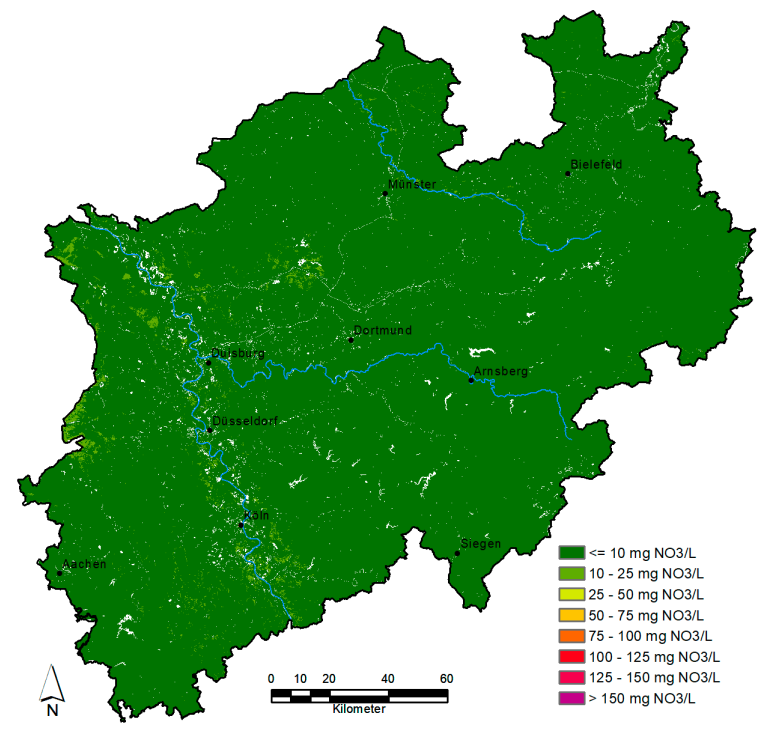

(b)

Figure 7. (a) Nitrate concentration in the leachate originating from urban systems and small sewage treatment plants, and (b) nitrate concentration in the leachate originating from the $N$ output from soil due to NOx deposition.

Figure 7a shows that the nitrate concentration in the leachate originating from urban systems and small sewage treatment plants ranged in most areas between 10 and $25 \mathrm{mg} / \mathrm{L}$ (e.g., in the entire Ruhr area). It was evident that the nitrate concentration in the leachate originating from these sources only to a minor extent and locally exceeds $50 \mathrm{mg} / \mathrm{L}$. As the areas concerned did not exceed $20 \%$ of the area of a groundwater body, no measures to reduce the $N$ emissions from urban systems and small sewage treatment plants had to be included in the program of measures according to EU-WFD requirements [14]. This, however, does not detract from the fact that measures to reduce $N$ output from urban systems may be necessary to improve surface water quality.

Figure $7 \mathrm{~b}$ shows the nitrate concentration in the leachate originating from $N O x$ deposition. For the latter, the denitrification in soil was accounted for as described in Equation (3). In most areas of North Rhine-Westfalia, the nitrate concentration in the leachate originating from NOx deposition was less than $10 \mathrm{mg} / \mathrm{L}$. In the southern part of the Lower Rhine Embayment, values of up to $25 \mathrm{mg} / \mathrm{L}$ occurred due to the low leachate rates (Figure 2). In conclusion, $N O x$ deposition did not at all lead to $\mathrm{NO}_{3}$ concentrations in the leachate above $50 \mathrm{mg} / \mathrm{L}$.

\subsection{Plausibility Check of Modelled Nitrate Concentration in the Leachate}

For comparing (modeled) nitrate concentrations in the leachate with (observed) nitrate concentrations in groundwater, it was necessary to merge the $N$ emissions from the individual $N$ sources. The corresponding nitrate concentrations in the leachate are represented in Figure 8 as the underlying colored areas. 

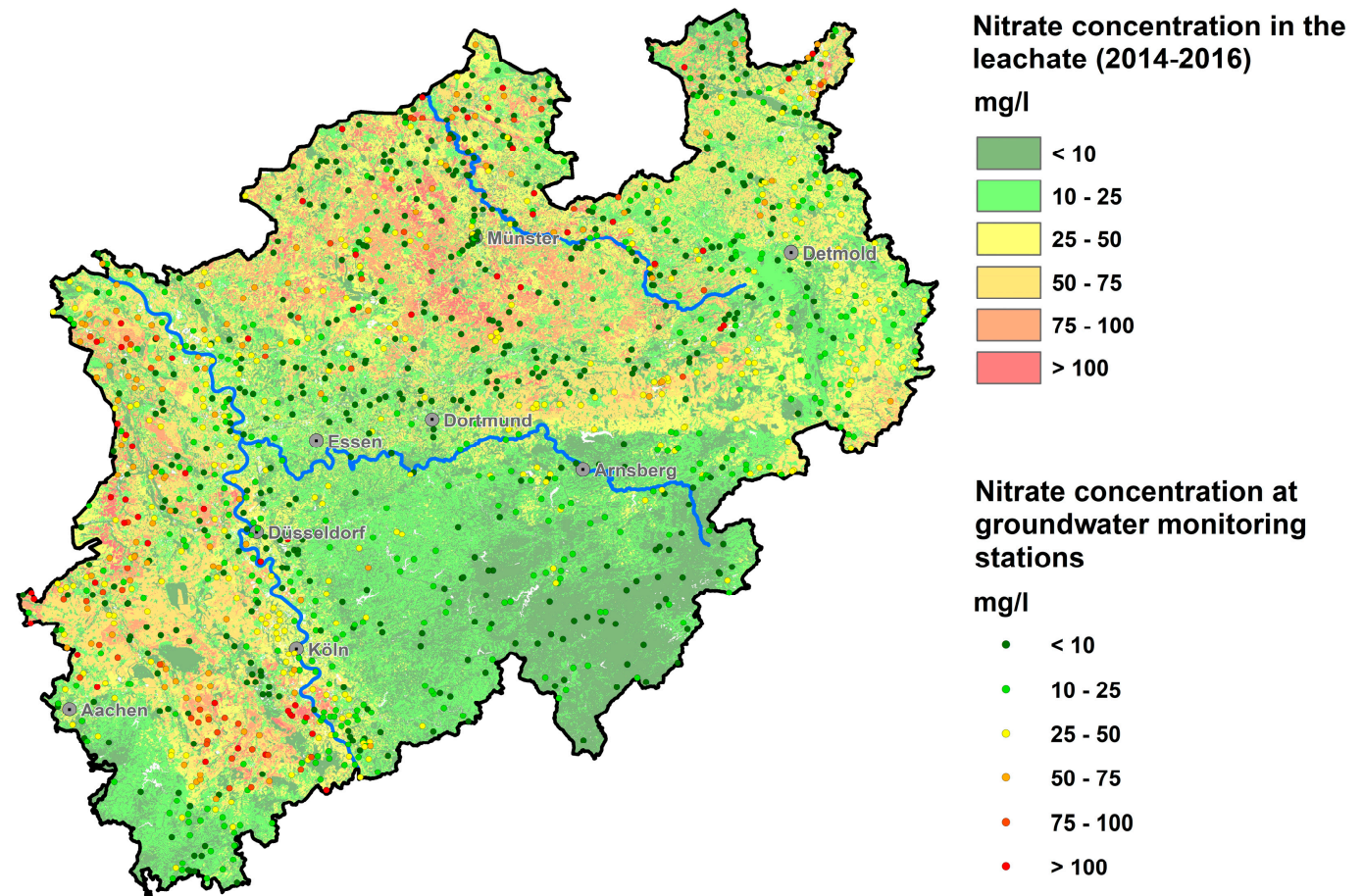

Figure 8. Plausibility check of the mean annual nitrate concentration in the leachate. The dots show observed values at groundwater monitoring sites-the underlying colored areas are the modelled nitrate concentrations in the leachate per grid.

The modelled nitrate concentration in the leachate was compared to nitrate concentrations observed at around 1500 groundwater monitoring stations from the upper aquifer for the period 2014 to 2017. In Figure 8, the mean values of the observed nitrate concentrations at the groundwater monitoring stations are represented as dots. For the comparison, the same class widths and the same color gradation were selected for both the underlying areas and the dots. The proportion of the main land use types (e.g., arable land, pasture, forest, settlement) occurring in North Rhine-Westfalia was approximately reflected by the distribution of the monitoring stations within these land use types, thus guaranteeing representability.

As can be seen from Figure 8, the modeled values in the Lower Rhine Embayment, the Weserbergland, and the Rhenish Massif corresponded spatially and with regard to their concentration levels very well to the observed nitrate concentrations in groundwater.

In the Münsterland, however, the modeled nitrate concentration in the leachate systematically exceeded the observed nitrate concentrations in groundwater (see Figure 8). There, due to the occurrence of denitrification capacities in the aquifers, the nitrate concentration in the leachate was decreased once the leachate entered into the groundwater. Consequently, the apparent disagreement between (high) modeled nitrate concentrations in the leachate and (low) observed nitrate concentrations in groundwater was attributable to the considerable denitrification capacity of reduced aquifers and did not indicate wrong model results [24].

The plausibility check described above was accompanied by a statistical evaluation of the modelled nitrate concentrations in leachate and the observed nitrate concentrations at monitoring stations for different land uses (Figure 9). 


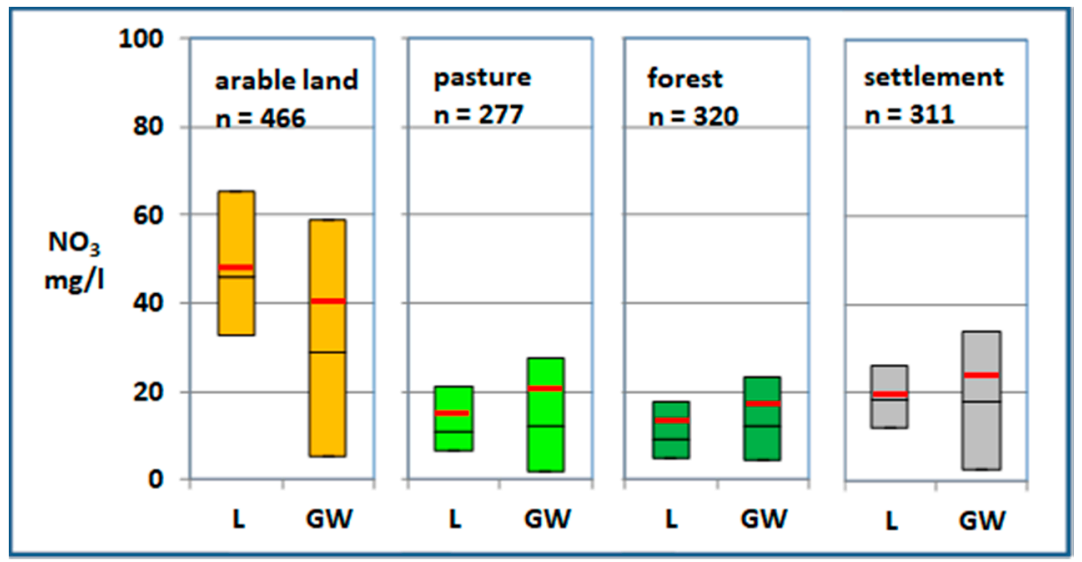

Figure 9. Comparison of modelled nitrate concentrations in the leachate $(\mathrm{L})$ and observed nitrate concentrations in groundwater at monitoring stations $(\mathrm{GW})$ for different land use types. The lower and upper end of the bars indicate the statistical distribution with the 25 th percentile and 75 th percentile, respectively, and the lines inside the bars mark the median (black line) and mean (red line).

Figure 9 shows that the 25th percentile and 75th percentile values, as well as the median and mean values of the modelled nitrate concentrations in the leachate and the observed nitrate concentrations in groundwater corresponded quite well for the land use classes of pasture, forests, and urban areas. For the land use class of arable land, however, the observed nitrate concentrations in groundwater showed lower values than the modelled nitrate concentrations in the leachate.

A more detailed analysis showed that the absence of denitrification capacities in aquifers explained the good agreement for the land use classes of pasture, forests, and settlements. Groundwater samples from these land use types showed oxidized groundwater, and thus the nitrate concentration in the leachate was preserved after infiltration into the upper aquifer $[18,31]$.

A considerable number of the groundwater monitoring stations from the land use class of arable land were, however, located in aquifers displaying high denitrification capacities, mainly in Münsterland (see Figure 8). As denitrification in groundwater was not accounted for in the modelled nitrate concentrations in the leachate, it was obvious that the modelled nitrate concentration in the leachate showed higher vales than the overserved nitrate concentrations in groundwater.

\section{Discussion}

The application of Equation (1) at the Federal State level was indispensable for assessing the entire $N$ loading of the leachate as well as the $N$ inputs into groundwater and surface waters. The grids showing nitrate concentrations in the leachate above $50 \mathrm{mg} \mathrm{NO} / \mathrm{L}$ represent the hot-spot areas of nitrate pollution of groundwater. The good correspondence of the modelled nitrate concentrations in the leachate with the observed nitrate concentrations in groundwater detected in the course of the plausibility check demonstrated that the model results were appropriate in indicating the nitrate pollution of groundwater at the Federal State level. Consequently, the modelled nitrate concentration in the leachate can be regarded as a reliable starting point for scenario analyses, for instance as an adequate reference value for assessing the extent to which a nitrate reduction is necessary to reach the EU-WFD quality target for groundwater.

Inside the groundwater bodies failing good quality status due to nitrate, the areas showing nitrate concentrations in the leachate above $50 \mathrm{mg} / \mathrm{L}$ were predestined for implementing $N$ reduction measures. Modelling nitrate concentration in the leachate apportioned between the individual agricultural and non-agricultural $N$ sources facilitated the identification of the main polluter in a certain region. It was obvious that only the latter had to implement measures to reduce the nitrogen impact on groundwater according to EU-WFD requirements. 
Results of the model analysis in North Rhine-Westfalia proved that $N$ emissions from small sewage plants, urban systems, and NOx deposition only locally caused nitrate concentrations in the leachate above $50 \mathrm{mg} \mathrm{NO}_{3} / \mathrm{L}$, in spite of the high population density (525 inhabitants $/ \mathrm{km}^{2}$ ). Consequently, as the areas concerned did not exceed $20 \%$ of the area of a groundwater body, the focus relied on agricultural measures to reduce nitrogen losses. This, however, did not detract from the fact that the implementation of measures to reduce the $N$ output from urban systems may have been necessary, but not within the program of measures according to EU-WFD.

Model analysis confirmed instead that $N$ emissions from agriculture exclusively led to extended areas of nitrate concentrations $>50 \mathrm{mg} \mathrm{NO}_{3} / \mathrm{L}$, especially in the north (Münsterland) and the west (Lower Rhine Embayment). As in general more than $20 \%$ of the areas in the respective groundwater bodies were concerned, the implementation of measures to reduce agricultural $N$ emissions in the context of the WFD program of measures was necessary.

Results presented for the Federal State of Northrhine-Westfalia clearly illustrated the importance of systematically considering not only agricultural $N$ emissions in modelling nitrate concentrations in the leachate. Especially in densely populated regions, the consideration of the $N$ inputs from all $N$ sources (as shown in the maps) was the only way to objectively assess the relevant polluter(s) in a region and to evaluate the relative contribution of each polluter to the overall $N$ pollution. The latter was once again important to dimension appropriate polluter-specific $N$ reduction measures.

A comparison of modelled nitrate concentrations in the leachate and observed nitrate concentrations in groundwater at monitoring stations for different land use types showed that the modelled nitrate concentration in the leachate showed higher vales than the overserved nitrate concentrations in groundwater due to denitrification processes in groundwater. The modelled high nitrate concentrations in the leachate were an indication that the $N$ emissions in groundwater have to be reduced. Even in cases where the observed nitrate concentrations in groundwater were found to be considerably below $50 \mathrm{mg} \mathrm{NO}_{3} / \mathrm{L}$, a reduction of the $\mathrm{N}$ emissions in groundwater is the only way to conserve the natural denitrification capacity of reduced aquifers for as long as possible [28].

Although the model can be recommended for large-scale assessments on the level of states or entire river basins, the use of the model results for local issues is subjected to several constraints. Most important are limitations in the local representativeness of the model input parameters derived from statewide available databases. It is evident that, for instance, on-site occurring soil properties may not be represented in a statewide available soil map at a scale of 1:50,000. Consequently, local obviously deviating model results may have been due to databases being insufficiently accurate for local issues. Therefore, an effective monitoring network and local expert knowledge will remain indispensable for implementing local nitrogen strategies. In this regard, it must also be remembered, that the modelled values represent reference values characterizing mean long-term conditions rather than fixed values tracing specific nitrate concentrations at certain sites and at certain times.

Author Contributions: Conceptualization: F.W., S.B., M.E., H.G., F.H., P.K., R.K.; Initial manuscript writing: F.W.; Review: S.B., M.E., H.G., F.H., P.K., R.K.; Methodology and investigation: F.W., S.B., M.E., H.G., F.H., P.K., R.K.; Visualization: M.E., R.K., F.W. All authors have read and agree to the published version of the manuscript.

Funding: This research was funded by the Ministry for Environment, Agriculture, Conservation and Consumer Protection of the State of North Rhine-Westphalia in the framework of the cooperation project GROWA+ NRW 2021.

Conflicts of Interest: The authors declare no conflict of interest.

\section{References}

1. Strebel, O.; Duynisveld, W.H.M.; Böttcher, J. Nitrate pollution of groundwater in Western Europe. Agric. Ecosyst. Environ. 1989, 26, 189-214. [CrossRef]

2. Sutton, M.A.; Howard, C.M.; Erisman, J.W.; Billen, G.; Bleeker, A.; Grennfelt, P.; van Grinsven, H.; Grizzetti, B. The European Nitrogen Assessment: Sources, Effects and Policy Perspectives; Cambridge University Press: Cambridge, UK, 2011; p. 612. 
3. Power, J.F.; Schepers, J.S. Nitrate contamination of groundwater in North America. Agric. Ecosyst. Environ. 1989, 26, 165-187. [CrossRef]

4. Rosenstock, T.S.; Liptzin, D.; Dzurella, K.; Fryjoff-Hung, A.; Hollander, A.; Jensen, V.; King, A.; Kourakos, G.; McNally, A.; Stuart Pettygrove, G.; et al. Agriculture's contribution to nitrate contamination of Californian groundwater (1945-2005). J. Environ. Qual. 2014, 43, 895-907. [CrossRef] [PubMed]

5. Thorburn, P.J.; Biggs, J.S.; Weier, K.L.; Keating, B.A. Nitrate in groundwaters of intensive agricultural areas in coastal Northeastern Australia. Agric. Ecosyst. Environ. 2003, 94, 49-58. [CrossRef]

6. Wu, M.; Wu, J.F.; Liu, J.; Wu, J.C.; Zheng, C.M. Effect of groundwater quality on sustainability of groundwater resource: A case study in the North China plain. J. Contam. Hydrol. 2015, 179, 132-147. [CrossRef] [PubMed]

7. Haller, L.; McCarthy, P.; O’Brien, T.; Riehle, J.; Stuhldreher, T. Nitrate Pollution of Groundwater; Alpha Water Systems Inc.: Paramount, CA, USA, 2013; Available online: http://www.reopure.com/nitratinfo.html (accessed on 10 July 2019).

8. Bechmann, M.; Blicher-Mathiesen, G.; Kyllmar, K.; Iital, A.; Lagzdins, A.; Salo, T. Nitrogen application, balances and the effect on nitrogen concentrations in runoff from small catchments in the Nordic-Baltic countries. Agric. Ecosyst. Environ. 2014, 198, 104-113. [CrossRef]

9. Billen, G.; Garnier, J.; Lassaletta, L. The nitrogen cascade from agricultural soils to the sea: Modeling nitrogen transfers at regional watershed and global scales. Philos. Trans. R. Soc. B 2013, 368, 1-13. [CrossRef]

10. EU-WFD. Directive 2000/60/EC of the European Parliament and the Council of 23 October 2000 Establishing a Framework for Community Action in the Field of Water Policy. Off. J. Eur. Communities 2000, L 327, 1-73.

11. EU-MSFD. Directive 2008/56/EC of the European Parliament and the Council of 17 June 2008 Establishing a Framework for Community Action in the Field of Marine Environmental Policy. Off. J. Eur. Communities 2008, L 164/19, 1-40.

12. European Parliament and Council of the European Union. Council Directive 91/676/EEC of 12 December 1991 Concerning the Protection of Waters against Pollution Caused by Nitrates from Agricultural Sources. Off. J. Eur. Communities 1991, L 375/1, 1-8.

13. Müller, D.; Blum, A.; Hart, A.; Hookey, J.; Kunkel, R.; Scheidleder, A.; Tomlin, F.; Wendland, F. Final Report for a Methodology to Set Up Groundwater Threshold Values in Europe; Report D18; Specific Targeted EU—Research Project Bridge: Vienna, Austria, 2006; pp. 1-63.

14. European Commission. Guidance on Groundwater Status and Trend Assessments, CIS Guidance Document No. 18, Luxembourg: Office for Official Publications of the European Communities; European Commission: Brussels, Belgium, 2009; p. 84.

15. Bikšel, J.; Retikel, I. An approach to delineate groundwater bodies at risk: Seawater intrusion in Liepāja (Latvia). E3S Web Conf. 2018, 54. [CrossRef]

16. Garrido, T.; Iglesias, M.; Fraile, J.; Munne, A. Chemical status assessment of groundwater bodies and measures proposed within the framework of the Catalan River basin district management plan. In Proceedings of the European Groundwater Conference, Madrid, Spain, 20-21 May 2010.

17. LAWA. Fachliche Umsetzung der Richtlinie zum Schutz des Grundwassers vor Verschmutzung und Verschlechterung 2006/118/EG; Sachstandsbericht vom 31.01.2008; LAWA-Unterausschuss, Fachliche Umsetzung der Grundwassertochterrichtlinie: Berlin, Germany, 2008.

18. Kuhr, P.; Haider, J.; Kreins, P.; Kunkel, R.; Tetzlaff, B.; Vereecken, H.; Wendland, F. Model based assessment of nitrate pollution of water resources on a federal state level for the dimensioning of agro-environmental reduction strategies: The North Rhine-Westphalia (Germany) case study. Water Resour. Manag. 2013, 27, 885-909. [CrossRef]

19. Wendland, F.; Bogena, H.; Goemann, H.; Hake, J.F.; Kreins, P.; Kunkel, R. Impact of nitrogen reduction measures on the nitrogen loads of the river Ems and Rhine (Germany). Phys. Chem. Earth 2009, 30, 527-541. [CrossRef]

20. van Berk, W.; Fu, Y. Redox roll-front mobilization of geogenic uranium by nitrate input into aquifers: Risks for groundwater resources. Environ. Sci. Technol. 2017, 51, 337-345. [CrossRef] [PubMed]

21. Rivett, M.O.; Buss, S.R.; Morgan, P.; Smith, J.W.N.; Bemment, C.D. Nitrate attenuation in groundwater: A review of biogeochemical controlling processes. Water Res. 2008, 42, 4215-4232. [CrossRef] [PubMed] 
22. Højberg, A.L.; Lausten Hansen, A.; Wachniew, P.; Żurek, A.J.; Virtanen, S.; Arustiene, J.; Strömqvist, J.; Rankinen, K.; Refsgaard, J.C. Review and assessment of nitrate reduction in groundwater in the Baltic Sea Basin. J. Hydrol. Reg. Stud. 2017, 12, 50-68. [CrossRef]

23. Kolbe, T.; de Dreuzy, J.R.; Abbott, B.W.; Aquilina, L.; Babey, T.; Green, C.T.; Fleckenstein, J.H.; Labasque, T.; Laverman, A.M.; Marçais, J.; et al. Stratification of reactivity determines nitrate removal in groundwater. Proc. Natl. Acad. Sci. USA 2019, 116, 2494-2499. [CrossRef]

24. Kunkel, R.; Bach, M.; Behrendt, H.; Wendland, F. Groundwater-borne nitrate intakes into surface waters in Germany. Water Sci. Technol. 2004, 49, 11-19. [CrossRef]

25. Kunkel, R.; Wendland, F.; Albert, H. Zum Nitratabbau in den grundwasserführenden Gesteinsschichten des Elbeeinzugsgebietes. Wasser Boden 1999, 51, 16-19.

26. Cremer, N.; Schindler, R.; Greven, K. Nitrateintrag ins Grundwasser und Abbaumechanismen an verschiedenen Fallbeispielen. Korresp. Wasserwirtsch. 2018, 11-16, 352-360.

27. Rohmann, U.; Sontheimer, H. Nitrat im Grundwasser: Ursachen, Bedeutung, Lösungswege; DVGWForschungsstelle am Engler-Bunte-Institut der Universität Karlsruhe: Karlsruhe, Germany, 1985; p. 468.

28. LAWA. Empfehlungen für eine harmonisierte Vorgehensweise zum Nährstoffmanagement (Defizitanalyse, Nährstoffbilanzen, Wirksamkeit landwirtschaftlicher Maßnahmen) in Flussgebietseinheiten. Produktdatenblätter 2017, 35-37, 42.

29. Fraters, D.; van Leeuwen, T.; Boumans, L.; Reijs, J. Use of long-term monitoring data to derive a relationship between nitrogen surplus and nitrate leaching for grassland and arable land on well-drained sandy soils in the Netherlands. Acta Agric. Scand. B Soil Plant 2005, 65, 144-154. [CrossRef]

30. Dalgaard, T.; Hansen, B.; Hasler, B.; Hertel, O.; Hutchings, N.J.; Jacobsen, B.H.; Stoumann Jensen, L.; Kronvang, B.; Olesen, J.E.; Schjørring, J.K.; et al. Policies for agricultural nitrogen management-Trends, challenges and prospects for improved efficiency in Denmark. Environ. Res. Lett. 2014, 9, 115002. [CrossRef]

31. Wendland, F.; Behrendt, H.; Gömann, H.; Hirt, U.; Kreins, P.; Kuhn, U.; Kunkel, R.; Tetzlaff, B. Determination of nitrogen reduction levels necessary to reach groundwater quality targets in large river basins: The Weser basin case study. Nutr. Cycl. Agroecosyst. 2009, 85, 63-78. [CrossRef]

32. Hirt, U.; Kreins, P.; Kuhn, U.; Mahnkopf, J.; Venohr, M.; Wendland, F. Management options to reduce future nitrogen emissions into rivers: A case study of the Weser river basin, Germany. Agric. Water Manag. 2012, 115, 118-131. [CrossRef]

33. Andelov, M.; Kunkel, R.; Uhan, J.; Wendland, F. Determination of nitrogen re-duction levels necessary to reach groundwater quality targets in Slovenia. Int. J. Environ. Sci. 2014, 29, 1806-1818.

34. Kunkel, R.; Herrmann, F.; Kape, H.E.; Keller, L.; Koch, F.; Tetzlaff, B.; Wendland, F. Simulation of terrestrial nitrogen fluxes in Mecklenburg-Vorpommern and scenario analyses how to reach $\mathrm{N}$-quality targets for groundwater and the coastal waters. Environ. Earth Sci. 2017, 76, 146. [CrossRef]

35. Wendland, F.; Kunkel, R.; Gömann, H.; Kreins, P. Water fluxes and diffuse nitrate pollution at the river basin scale: Interfaces for the coupling of agroeconomical models with hydrological approaches. Water Sci. Technol. 2007, 55, 133-142. [CrossRef]

36. Wakidaa, F.T.; Lerner, D.N. Non-agricultural sources of groundwater nitrate: A review and case study. Water Res. 2005, 39, 3-16. [CrossRef] [PubMed]

37. Zhang, Q.; Sun, J.; Liu, J.; Huang, G.; Lu, C.; Zhang, Y. Driving mechanism and sources of groundwater nitratecontamination in the rapidly urbanized region of south China. J. Contam. Hydrol. 2015, 182, 221-230. [CrossRef] [PubMed]

38. Wikipedia. Available online: https://de.wikipedia.org/wiki/Metropolregion_Rhein-Ruhr (accessed on 20 November 2019).

39. Henrichsmeyer, W.; Cypris, C.; Löhe, W.; Meudt, M.; Sander, R.; von Sothen, F.; Isermeyer, F.; Schefski, A.; Schleef, K.-H.; Neander, E.; et al. Entwicklung Eines Gesamtdeutschen Agrarsektormodells RAUMIS96. Endbericht zum Kooperationsprojekt; Forschungsbericht für das BML (94 HS 021); Vervielfältigtes Manuskript: Bonn/Braunschweig, Germany, 1996.

40. Kreins, P.; Gömann, H.; Herrmann, S.; Kunkel, R.; Wendland, F. Integrated agricultural and hydrological modeling within an intensive livestock region. Adv. Econ. Environ. Res. 2007, 7, 113-142. 
41. Heidecke, C.; Hirt, U.; Kreins, P.; Kuhr, P.; Kunkel, R.; Mahnkopf, J.; Schott, M.; Tetzlaff, B.; Venohr, M.; Wagner, A.; et al. Endbericht zum Forschungsprojekt "Entwicklung Eines Instrumentes für ein Flussgebietsweites Nährstoffmanagement in der Flussgebietseinheit Weser" AGRUM+-Weser; Thünen Report 21; Johann Heinrich von Thünen-Institut: Braunschweig, Germany, 2015; 380p. [CrossRef]

42. Wendland, F. Die Nitratbelastung in den Grundwasserlandschaften der "Alten" Bundesländer (BRD); Berichte aus der Ökologischen Forschung 8; Forschungszentrum Jülich Germany: Juelich, Germany, 1992; p. 150.

43. Wienhaus, S.; Höper, H.; Eisele, M.; Meesenburg, H.; Schäfer, W. Nutzung Bodenkundlich-Hydrogeologischer Informationen zur Ausweisung von Zielgebieten für den Grundwasser-Schutz-Ergebnisse Eines Modellprojektes (NOLIMP) zur Umsetzung der EG—Wasserrahmenrichtlinie; GeoBerichte 9; Landesamt für Bergbau, Energie und Geologie: Hannover, Germany, 2008; 56p.

44. Herrmann, F.; Keller, L.; Kunkel, R.; Vereecken, H.; Wendland, F. Determination of spatially differentiated water balance components including groundwater recharge on the federal state level-A case study using the mGROWA model in North Rhine-Westphalia (Germany). J. Hydrol. Reg. Stud. 2015, 4, 294-312. [CrossRef]

45. Herrmann, F.; Kunkel, R.; Ostermann, U.; Vereecken, H.; Wendland, F. Projected impact of climate change on irrigation needs and groundwater resources in the metropolitan area of Hamburg (Germany). Environ. Earth Sci. 2016, 75, 1104. [CrossRef]

46. Engel, N.; Müller, U.; Schäfer, W. BOWAB_Ein Mehrschicht-Bodenwasserhaushaltsmodell. GeoBerichte 2012, 20, 85-98.

47. Wendland, F.; Kunkel, R.; Grimvall, A.; Kronvang, B.; Muller-Wohlfeil, D.I. Model system for the management of nitrogen leaching at the scale of river basins and regions. Water Sci. Technol. 2001, 43, 215-222. [CrossRef] [PubMed]

48. Kunkel, R.; Wendland, F. WEKU-A GIS-supported stochastic model of groundwater residence times in upper aquifers for the supraregional groundwater management. J. Environ. Geol. 1997, 1-2, 1-9. [CrossRef]

49. Böttcher, J.; Strebel, O.; Duynisveld, W.H.M. Kinetik und Modellierung gekoppelter Stoffumsetzungen im Grundwasser eines Lockergesteinsaquifers. Geol. Jahrb. 1989, 51, 3-40.

50. van Beek, C.G.E.M. Landdbouw en Drinkwatervoorziening, orientierend Onderzoek Naar de Beinvloeding can de Grondwaterkwaliteit Door Bemesting en Het Gebruik van Bestrijdings-Middelen; Keuringsinstituut Voor Waterleidingsartikelen Kiwa NV: Nieuwegein, The Netherlands, 1987.

51. Walther, W.; Reinstorf, F.; Pätsch, M.; Weller, D. Management tools to minimize nitrogen emissions into groundwater in agricultural used catchment areas, northern low plain of Germany. In Proceedings of the XXX IAHR Congress-Water Engineering and Research in a Learning Society, Thessaloniki, Greece, 24-29 August 2003; pp. 747-754.

52. Venohr, M.; Hirt, U.; Hofmann, J.; Opitz, D.; Gericke, A.; Wetzig, A.; Natho, S.; Neumann, F.; Hürdler, J.; Matranga, M.; et al. Modelling of nutrient emissions in river systems-MONERIS-Methods and Background. Int. J. Hydrobiol. 2011, 96, 435-483. [CrossRef]

53. Behrendt, H.; Opitz, D. Retention of nutrients in river systems: Dependence of specific runoff and hydraulic load. Hydrobiologia 2000, 410, 111-122. [CrossRef]

54. OSPAR Commission. Principles of the Comprehensive Study on Riverine Inputs and Direct Discharges (RID); OSPAR Commission: Southhampton, UK, 1998; 16p.

55. Schaap, M.; Hendriks, C.; Kranenburg, R.; Kuenen, J.; Segers, A.; Schlutow, A.; Nagel, H.D.; Ritter, A.; Banzhaf, S. PINETI-3: Modellierung Atmosphärischer Stoffeinträge von 2000 bis 2015 zur Bewertung der ökosystem-Spezifischen Gefährdung von Biodiversität Durch Luftschadstoffe in Deutschland; UBA-Texte 79/2018; Umweltbundesamt: Dessau, Germany, 2018; 149p.

56. Kunkel, R.; Wendland, F. The GROWA98 model for Water balance analysis in large river basins-The river Elbe case study. J. Hydrol. 2002, 259, 152-162. [CrossRef]

57. Schäfer, W.; Höper, H.; Müller, U. Diffuse nitrat- und phosphatbelastung-Ergebnisse der bestandsaufnahme der EUWRR in Niedersachsen. Geoberichte 2007, 2, 3-32.

58. Schaap, M.; Banzhaf, S.; Scheuschner, T.; Geupel, M.; Hendriks, C.; Kranenburg, R.; Nagel, H.-D.; Segers, A.; von Schlutow, A.; Wichink, R.; et al. Atmospheric nitrogen deposition to terrestrial ecosystems across Germany. Biogeosciences 2017. [CrossRef] 
59. MKULNV. Entwicklung und Stand der Abwasserbeseitigung in Nordrhein-Westfalen; Ministerium für Klimaschutz, Umwelt, Landwirtschaft, Natur- und Verbraucherschutz Nordrhein-Westfalen: Düsseldorf, Germany, 2014; Available online: https://www.umwelt.nrw.de/fileadmin/redaktion/Broschueren/abwasserbeseitigung entwicklung_kurzfassung.pdf (accessed on 28 November 2019).

60. DEA-Datendrehscheibe. 2016. Available online: https://www.elwasweb.nrw.de/elwas-web/index.jsf\# (accessed on 17 July 2018).

(c) (1)

(C) 2020 by the authors. Licensee MDPI, Basel, Switzerland. This article is an open access article distributed under the terms and conditions of the Creative Commons Attribution (CC BY) license (http://creativecommons.org/licenses/by/4.0/). 